\title{
Consumer Perception and Understanding of European Union Quality Schemes: A Systematic Literature Review
}

\author{
Alexandra-Ioana Glogovețan ${ }^{1}\left(\mathbb{D}\right.$, Dan-Cristian Dabija ${ }^{2}\left(\right.$, , Mariantonietta Fiore ${ }^{3}$ and Cristina Bianca Pocol ${ }^{1, *(\mathbb{D})}$ \\ 1 Department of Animal Production and Food Safety, University of Agricultural Sciences and Veterinary \\ Medicine of Cluj-Napoca, 400372 Cluj-Napoca, Romania; alexandra.glogovetan@gmail.com \\ 2 Department of Marketing, Babeș-Bolyai University Cluj-Napoca, 400591 Cluj-Napoca, Romania; \\ dan.dabija@ubbcluj.ro \\ 3 Department of Economics, University of Foggia, 71121 Foggia, Italy; mariantonietta.fiore@unifg.it \\ * Correspondence: cristina.pocol@usamvcluj.ro
}

check for

updates

Citation: Glogovețan, A.-I.;

Dabija, D.-C.; Fiore, M.; Pocol, C.B.

Consumer Perception and

Understanding of European Union

Quality Schemes: A Systematic

Literature Review. Sustainability 2022,

14, 1667. https://doi.org/10.3390/

su14031667

Academic Editors

Mariarosaria Lombardi,

Vera Amicarelli and Erica Varese

Received: 21 December 2021

Accepted: 27 January 2022

Published: 31 January 2022

Publisher's Note: MDPI stays neutral with regard to jurisdictional claims in published maps and institutional affiliations.

Copyright: (c) 2022 by the authors. Licensee MDPI, Basel, Switzerland. This article is an open access article distributed under the terms and conditions of the Creative Commons Attribution (CC BY) license (https:// creativecommons.org/licenses/by/ $4.0 /)$.

\begin{abstract}
Food, agriculture, and labeling, affecting the environment are well connected concepts, the balance between them being determined not only by pedological and climatic factors or the development level of agricultural techniques, but also by national governments and international organizations' food processing, trade policies and regulations. In this context, the European Union (EU) encourages the use of different food quality schemes: "Protected Designation of Origin" (PDO), "Protected Geographical Indication" (PGI), and "Traditional Specialty Guaranteed" (TSG) to protect producers of special-quality foods and assist consumers in their purchasing decisions. This review examines existing studies on the impact of these labels on customers behavior. A total of 32 studies were found and systematized. The papers were selected if they featured unique empirical research on consumer perceptions of any of PDO, PGI and TSG labels. Using the search strategy, a literature analysis was performed based on papers extracted from Web of Science, Springer Link, Emerald Insights, and Science Direct. Although these papers highlight quite diversified findings, the internationally used labels play an increasing role in contemporary society and pandemic conditions caused by COVID-19, thus making the quality schemes relevant in consumer decision-making processes.
\end{abstract}

Keywords: "Protected Designation of Origin" (PDO); "Protected Geographical Indication" (PGI); "Traditional Specialty Guaranteed" (TSG); “Geographical Indication" (GI); EU quality labels; consumer behavior

\section{Introduction}

Agriculture is of vital importance to the society, environment, and economy of the European Union [1]. Proper environmental conditions support agricultural activities, allowing farmers to use natural resources, create products and earn their living. In addition, agrarian income sustains farmers and families in rural communities, while agri-food strengthens society [1,2].

The next decade, starting with 2021, represents the transition to "smart" food that is more efficient, healthier, and greener, as it is obtained from the "smart" agriculture system [3]. The agricultural policies of the EU are based on specific measures regarding the development of entire food chains, from production and distribution to consumption, aiming at reducing food waste [4]. Public policies will have a pivotal role in protecting the availability, accessibility, and quality of agri-food products [2]. Therefore, agri-food products that are certified with quality schemes represent an ideal food product because they are manufactured from raw materials, being developed according to specific production methods, and technologies in a well-defined geographical area. These products are characterized by natural factors of production, traditions and/or specific historical procedures developed over centuries that cannot be replaced [5]. 
Thus, the supply chain of environmentally friendly products becomes a preferential reference point for both producers and consumers and allows a redefinition of financial support instruments to increase the efficiency of production and distribution processes, especially those affecting the environment [6]. Therefore, small and medium-sized companies located in different areas of the EU represent the ideal framework for quality food production (such as Geographical Indication or organic), which could move towards an economically and socially sustainable solution [6].

In the European Union, product names are protected by registering them in so called "quality schemes", which means that they entail unique characteristics such as a certain geographical origin, traditional manufacturing technologies and/or long-lasting practices [7]. Quality schemes have the following features: (1) most production stages must be implemented in a delimited geographical area, (2) the recipe after they are manufactured is authentic (mixture of ingredients); the raw materials are original, the production process is traditional and/or contains specific features for that region, (3) are available on the market for at least 50 years and (4) share a part of the gastronomic heritage of a society/community $[7,8]$.

The EU's geographical indication system thus provides protection for products names from various regions around the world, which have some unique features or enjoys a stable reputation, depending on the territory where they are produced. Geographical indications include "PDO—Protected Designation of Origin" (food and wine), "PGI—Protected Geographical Indication" (food and wine), "GI-Geographical Indication" (for alcoholic beverages) [7]. Other quality certification systems highlight the traditional production process ("Traditional Specialty Guaranteed") - TSG—or some products that are made in more challenging areas, such as mountains (mountain products). When considering the characteristics of PDO and PGI, the main differences relate to the proportion of raw materials (at least 85 percent) that are usually common for the area where they come from, but also on the production stages, that must be implemented in the considered geographical region. GI is typical for spirits and aromatic wines [7].

The PDO quality label represents a proper reference for the manufacturing place of agri-food products. Thus, all transformation stages from the raw materials to the final product must take place in a particular region. As for wines, the essential condition is that the raw material (grapes) comes exclusively from the site where the wine will be produced [7]. The PGI label pinpoints the connection between a certain geographical region and a certain product brand. In this situation, at least one of the production steps must be implemented at the place of origin. Concerning PGI-certified wines, $85 \%$ of the raw materials (grapes) must have their origin only in the geographical area where the wine will be produced [7].

The "Traditional Specialty Guaranteed" (TSG) emphasizes many traditional aspects, such as the composition and ingredients, a specific recipe, without being necessary connected to any specific geographical area. The name of a registered TSG product protects it from being falsified or misused [7]. TSG certified agri-food products could be manufactured by any producer who respects this production method. Their 'specific' character refers to the characteristics that differentiate them from other foodstuffs belonging to the same category. Even if agri-food products certified with the TSG quality scheme often come from a particular country or region, their international reputation might result in the interest of producers from other countries in them [7].

By allowing producer groups to mark and label the origin of their products, quality schemes provide a means to protect traditional products' integrity and prevent and avoid abuse and counterfeiting [9]. Each of these certifications is represented graphically through logos, after which the certified products can be recognized (Table 1).

Through these logos (Table 1), agricultural producers can communicate the product's characteristics and quality attributes to consumers, thus ensuring fair competition, intellectual property rights, and an integrated internal market $[10,11]$. Consequently, the main benefits for consumers are identified as follows: producers of agri-food products 
certified with quality schemes are required to provide reliable information on the origin of their products. They must guarantee that the products are authentic goods, not fakes or imitations (confirmed to the final consumer by the logo attached to the product packaging and charging a higher price than other foods in the same category). Thus, by purchasing certified agri-food products, the consumer can recognize products from their region or other regions [12,13]. In Europe, there are numerous agricultural products and alcoholic beverages certified with European quality schemes. The table below (Table 2) provides an official statistic containing the number of products registered and protected with quality schemes from each country. The first position is occupied by Italy. Figure 1 shows the situation of PDO/PGI/GI/TSG products by country in descending order (status-registered, all application type).

As Figure 2 shows, the interest in consumer-focused studies is concentrated across European countries. This fact is because most of the agri-food products and the alcoholic beverages certified with European quality schemes are from the territory of the European Union.

In the light of the above-mentioned arguments, the purpose of this paper is to provide an outline of what is acknowledged about the perception, willingness to pay, and buying behavior of food products certified with PDO, PGI, and TSG schemes. At the same time, there is a lack of studies linking the origin of PDO/PGI/TSG to healthy eating in the context of COVID 19-pandemic today. This review can serve as a starting point for discussions about the utility and advantage of these quality schemes as a marketing tool for the stakeholders involved (from producers to final consumers) to promote market transparency and food quality in pandemic times.

The following section discusses the materials and methods employed. The third section describes the results, divided between the jurisdiction and methodologies used by the reviewed studies. They are sorted according to the declared perception of consumers, preferences, recognition, and willingness to pay for certified agri-food products, purchasing and consumption behaviors towards certified agri-food products, and online purchasing of certified agri-food products. The fourth section presents critical discussions, while the final section pinpoints the conclusions for theory, the implications for market participants and public institutions, along with the limitations and further research directions.

Table 1. The different quality schemes of the EU.

EU Quality Schemes


Table 2. Agricultural Products, Foodstuffs and Alcoholic Beverages-Status: Registered.

\begin{tabular}{|c|c|c|c|c|c|}
\hline \multirow{3}{*}{ Country } & \multicolumn{2}{|c|}{ Number of Agricultural Products and Foodstuffs Registered * } & \multicolumn{3}{|c|}{ Number of Alcoholic Beverages Registered * } \\
\hline & \multirow{2}{*}{ PDO/PGI } & \multirow{2}{*}{ TSG } & PDO/PGI & GI & TSG \\
\hline & & & Wine & Spirit Drinks & Beers \\
\hline Austria & 16 & 3 & 27 & 9 & 0 \\
\hline Belgium & 16 & 0 & 10 & 10 & 5 \\
\hline Bulgaria & 3 & 6 & 54 & 12 & 0 \\
\hline Croatia & 33 & 0 & 18 & 6 & 0 \\
\hline Republic of Cyprus & 9 & 0 & 11 & 2 & 0 \\
\hline Czech Republic & 30 & 1 & 13 & 0 & 0 \\
\hline Denmark & 8 & 0 & 5 & 0 & 0 \\
\hline Estonia & 1 & 0 & 0 & 1 & 0 \\
\hline Finland & 7 & 2 & 0 & 2 & 1 \\
\hline France & 258 & 2 & 437 & 53 & 0 \\
\hline Germany & 93 & 0 & 45 & 35 & 0 \\
\hline Greece & 113 & 1 & 147 & 15 & 0 \\
\hline Hungary & 28 & 2 & 38 & 12 & 0 \\
\hline Ireland & 8 & 0 & 0 & 3 & 0 \\
\hline Italy & 313 & 6 & 526 & 34 & 0 \\
\hline Latvia & 3 & 4 & 0 & 0 & 0 \\
\hline Lithuania & 7 & 2 & 0 & 7 & 0 \\
\hline Luxembourg & 4 & 0 & 1 & 0 & 0 \\
\hline Malta & 0 & 0 & 3 & 0 & 0 \\
\hline Norway & 2 & 0 & 0 & 2 & 0 \\
\hline Netherlands & 11 & 5 & 18 & 5 & 0 \\
\hline Poland & 34 & 11 & 0 & 2 & 0 \\
\hline Portugal & 140 & 2 & 40 & 11 & 0 \\
\hline Romania & 9 & 1 & 53 & 9 & 0 \\
\hline Slovakia & 13 & 3 & 9 & 1 & 0 \\
\hline Slovenia & 23 & 4 & 17 & 4 & 0 \\
\hline Spain & 200 & 4 & 140 & 19 & 0 \\
\hline Sweden & 8 & 2 & 0 & 3 & 0 \\
\hline Turkey & 7 & 0 & 0 & 0 & 0 \\
\hline United Kingdom & 69 & 6 & 5 & 5 & 0 \\
\hline TOTAL & 1466 & 67 & 1617 & 262 & 6 \\
\hline
\end{tabular}

Note: * Agricultural Products, Foodstuffs and Alcoholic Beverages-Status: Registered until 29 January 2022 Andorra and Iceland: 1 food PDO/PGI quality scheme; the Russian Federation: 1 Spirit Drinks quality scheme; Serbia and Switzerland: 1 Wine quality schemes; Belarus: 2 food PDO/PGI quality scheme. Source: [14].

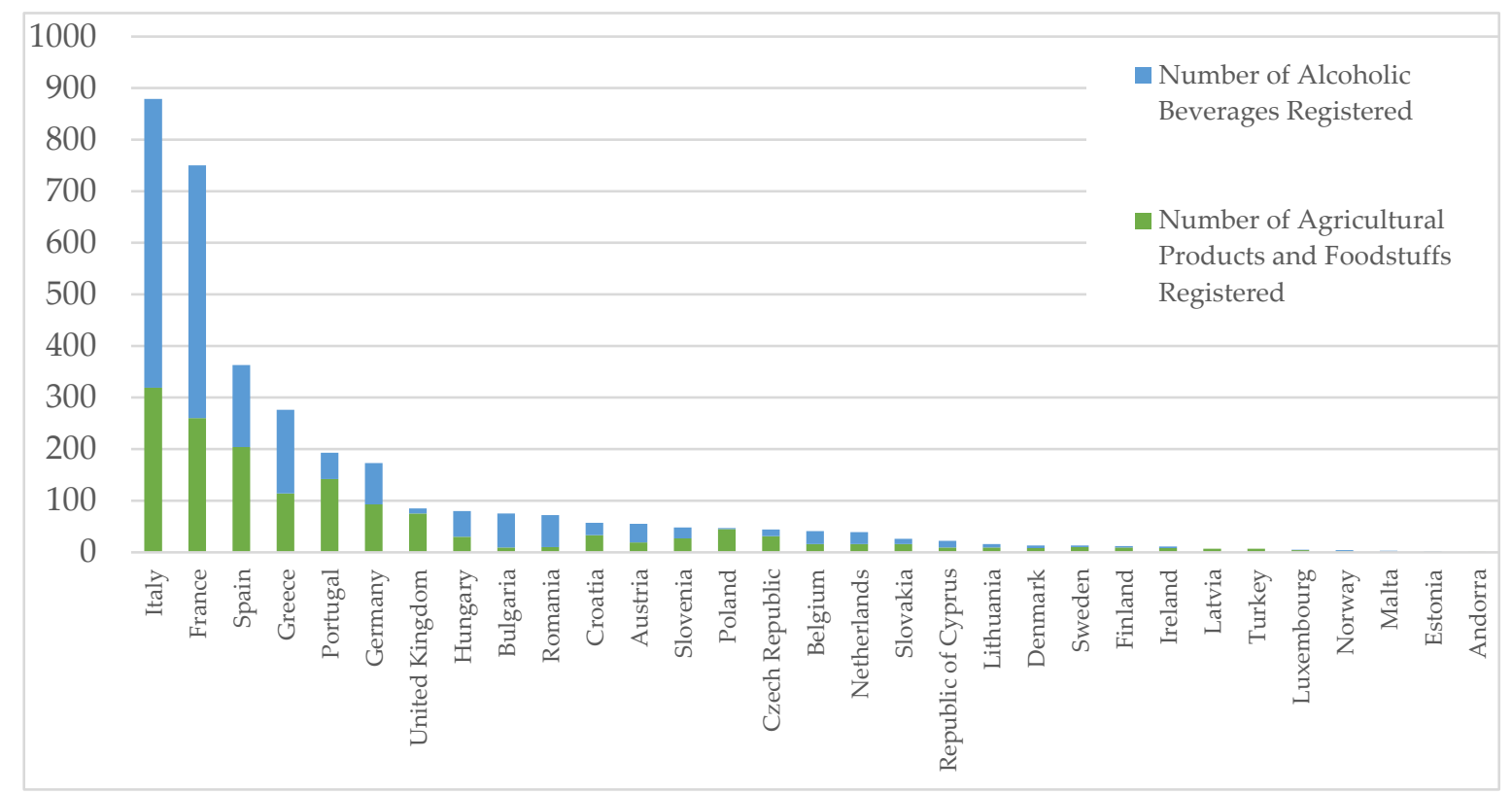

Figure 1. Statistic of PDO/PGI/GI/TSG products sorted by country. Source: Own development. Note: Agricultural products, foodstuffs and alcoholic beverages registered until 16 January 2022. 


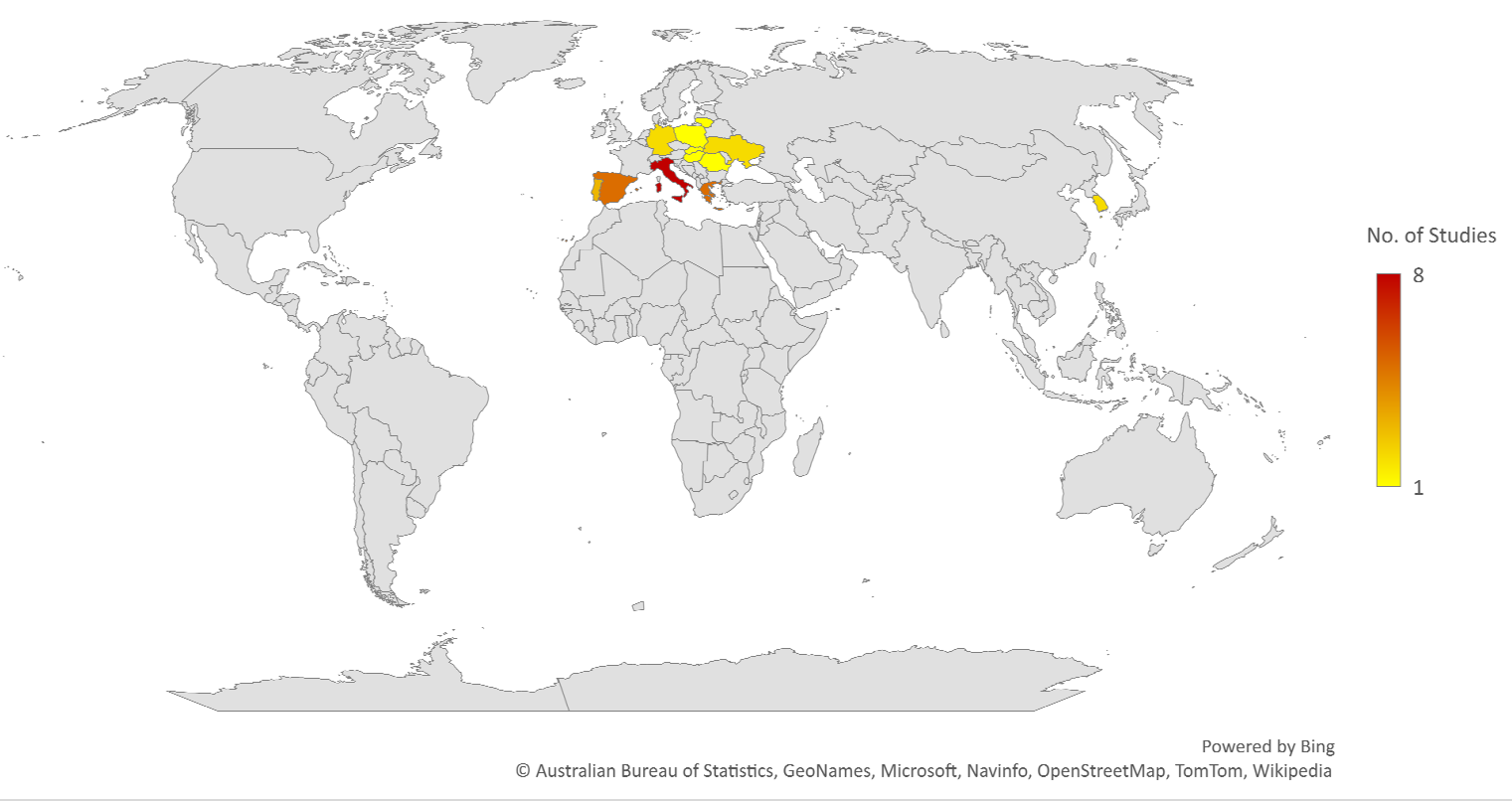

Figure 2. Geographic heatmap based on revised literature jurisdictions. Source: Own development. Note: The range of 1 by 8 is the maximum number of revised studies from a country.

\section{Materials and Methods}

Using the search strategy reported by Campos et al. [15] and Grunert and Aaachman [16], a literature analysis was performed through a combination of the following keywords (Figure 3) in Web of Science, and others relevant international databases according to their international visibility and authors library access (Springer Link, Emerald Insight, Science Direct). The main research directions identified are composed of the consumers' perceptions about certified agri-food products, preference, recognition, willingness to pay, and purchasing and consumption behavior of certified agri-food products. More recent studies discussing the online purchasing of certified agri-food products are also reviewed.

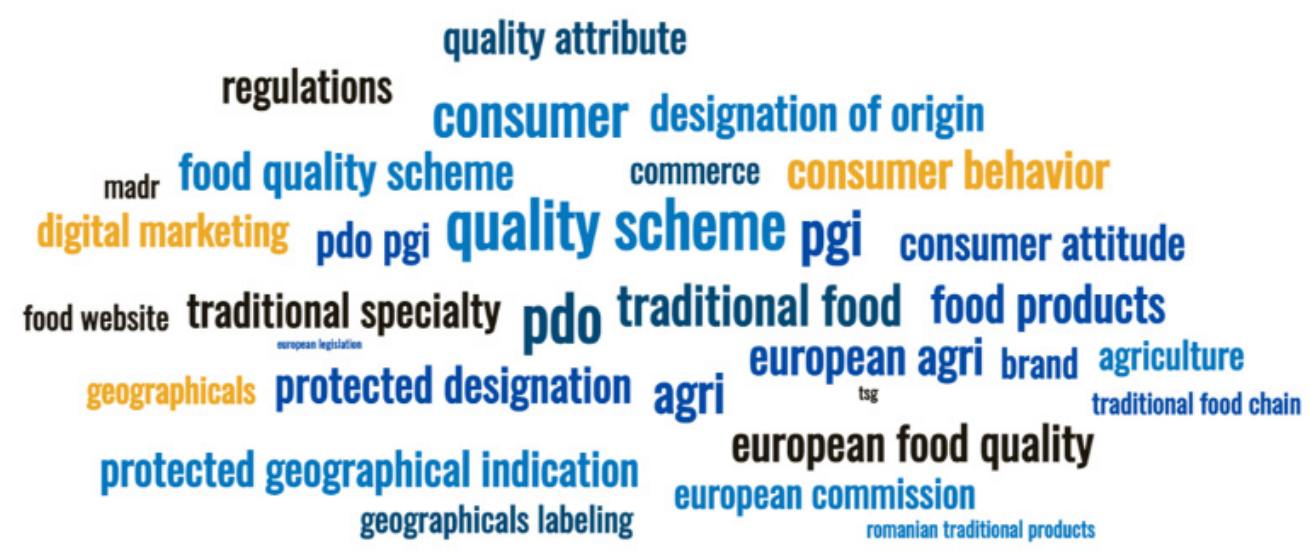

Figure 3. Keywords cloud. Source: Own development.

The initial search generated 79 papers, of which 37 titles fit the considered criteria (see Table 3), therefore being further analyzed. The publications were evaluated to pinpoint if they deal with one or more of the registered EU quality schemes. The papers were selected only if they featured unique empirical research on consumer perceptions of any of PDO, PGI and TSG labels. These publications were retained for further analysis only if they fulfilled simultaneously the eight methodological criteria proposed by Campos et al. [15] 
and Olbrich et al. [16]. The final set of papers included in the present systematic literature review consist of 32 publications.

Table 3. The methodological criteria.

\begin{tabular}{lc}
\hline \multicolumn{1}{c}{ Criterion } & Possible Outcome \\
\hline 1. "Is the research question well stated?" & Y/N \\
2. "Is the sample/population identified and appropriate?" & Y/N \\
3. "Are the inclusion/exclusion criteria described and appropriate?" & Y/N or N/A \\
4. "If applicable, is the participation rate reported and appropriate?" & Y/N or N/A \\
5. "Is the same data collection method used for all respondents?" & Y/N \\
6. "Are important the variables, well measured, valid, and reliable?" & Y/N or N/A \\
7. "Is the outcome defined and measurable?" & Y/N \\
8. "Is the statistical analysis appropriate?" & Y/N or N/A \\
\hline
\end{tabular}

Note: Y states for Yes; N states for No; Y/N states for Not applicable. Source: [15,16].

\section{Results}

In implementing the research scope, the main results of the conceptual framework are reviewed. The results are divided between the jurisdiction and methodologies used by the reviewed studies; and they are sorted according to the following: the declared perception of consumers from the identified papers about certified agri-food products, preferences, recognition, and willingness to pay for certified agri-food products, purchasing and consumption behaviors towards certified agri-food products, and online purchasing of certified agri-food products.

\subsection{Jurisdiction and Methodologies}

The 32 revised articles (Table 4) originate from the following jurisdictions: Italy, Poland, Lithuania, Slovakia, Romania, Ukraine, Hungary, Spain, Portugal, Greece, Germany, and South Korea. The online questionnaire represents the most used study tool. The papers also used PAPI and CAWI surveys, Eurobarometer surveys, online consumer databases, and household journals conceived by consumers participating in the study. Regarding the analyses applied, cross-sectional analysis, Partial Least Square path modelling, multi-group analysis, Structural Equations Modelling, Web content analysis, ANOVA, and eMICA analysis were mainly used. The samples on which the studies were conducted are various and range from 150 respondents to 35,000 respondents. The certified agri-food products with quality schemes on which the studies were carried out are mainly olive oil, wine, meat, and cheese. Most of the studies reviewed focused on all three labels: PDO, PGI, and TSG. The rest of the studies performed analyses based on agri-food products certified either with PDO or TSG.

Table 4. Journals and citations of the reviewed literature.

\begin{tabular}{|c|c|c|c|c|}
\hline Title & Authors & $\begin{array}{l}\text { Journal } \\
\text { of Publication }\end{array}$ & $\begin{array}{l}\text { Publication } \\
\text { Year }\end{array}$ & $\begin{array}{c}\text { Total } \\
\text { Citations * }\end{array}$ \\
\hline $\begin{array}{l}\text { How Much Do Consumers Value Protected } \\
\text { Designation of Origin Certifications? Estimates of } \\
\text { Willingness to Pay for PDO Dry-Cured Ham in Italy }\end{array}$ & Garavaglia, C.; Mariani, P. & $\begin{array}{l}\text { Agribusiness } \\
\text { (New York) }\end{array}$ & 2017 & 29 \\
\hline $\begin{array}{l}\text { PDO Labels and Food Preferences: Results from a } \\
\text { Sensory Analysis }\end{array}$ & $\begin{array}{l}\text { Savelli, E.; Bravi, L.; } \\
\text { Francioni, B.; Murmura, F.; } \\
\text { Pencarelli, T. }\end{array}$ & Br. Food J. & 2021 & 3 \\
\hline $\begin{array}{l}\text { Premium Private Labels Products: Drivers of } \\
\text { Consumers' Intention to Buy }\end{array}$ & Martinelli, E.; De Canio, F. & $\begin{array}{l}\text { Int. J. Bus. } \\
\text { Manag. }\end{array}$ & 2019 & 1 \\
\hline $\begin{array}{l}\text { Consumers' Trust in Greek Traditional Foods in the } \\
\text { Post COVID-19 Era }\end{array}$ & $\begin{array}{l}\text { Skalkos, D.; Kosma, I. S.; } \\
\text { Vasiliou, A.; Guine, R. P. F. }\end{array}$ & Sustainability & 2021 & 1 \\
\hline $\begin{array}{l}\text { Perceived Risk Factors Affecting Consumers' Online } \\
\text { Shopping Behaviour }\end{array}$ & $\begin{array}{l}\text { Tham, K. W.; Dastane, O.; } \\
\text { Johari, Z.; Ismail, N.B. }\end{array}$ & $\begin{array}{l}\text { J. Asian Finance } \\
\text { Econ. Bus. }\end{array}$ & 2019 & 60 \\
\hline $\begin{array}{l}\text { Consumer Reactions to the Use of EU Quality Labels } \\
\text { on Food Products: A Review of the Literature }\end{array}$ & Grunert, K.G.; Aachmann, K. & Food Control & 2016 & 183 \\
\hline
\end{tabular}


Table 4. Cont.

\begin{tabular}{|c|c|c|c|c|}
\hline Title & Authors & $\begin{array}{c}\text { Journal } \\
\text { of Publication }\end{array}$ & $\begin{array}{l}\text { Publication } \\
\text { Year }\end{array}$ & $\begin{array}{c}\text { Total } \\
\text { Citations * }\end{array}$ \\
\hline $\begin{array}{l}\text { Gastronomy as a tourism resource in the province of } \\
\text { Alicante }\end{array}$ & $\begin{array}{l}\text { Martínez, A.A.; } \\
\text { Fernández-Poyatos, M.D. }\end{array}$ & $\begin{array}{l}\text { Int. J. of Sci. } \\
\text { Mgmt. and } \\
\text { Tourism }\end{array}$ & 2017 & $\mathrm{~N} / \mathrm{A}$ \\
\hline Promotion of Regional and Traditional Products & Oleksiuk, I.; Werenowska, A. & Środ. Stud. Polit. & 2019 & 1 \\
\hline $\begin{array}{l}\text { Premium Private Labels and PDO/PGI Products: } \\
\text { Effects on Customer Loyalty }\end{array}$ & $\begin{array}{l}\text { Martinelli, E.; De Canio, F.; } \\
\text { Marchi, G.; Nardin, G. }\end{array}$ & $\begin{array}{l}\text { Advances in } \\
\text { National Brand } \\
\text { and Private Label } \\
\text { Marketing. }\end{array}$ & 2017 & 4 \\
\hline $\begin{array}{l}\text { Organic and Online Attributes for Buying and Selling } \\
\text { Agricultural Products in the E-Marketplace in Spain }\end{array}$ & $\begin{array}{l}\text { Robina-Ramírez, R.; } \\
\text { Chamorro-Mera, A.; } \\
\text { Moreno-Luna, L. }\end{array}$ & $\begin{array}{l}\text { Electron. Commer. } \\
\text { Res. Appl. }\end{array}$ & 2020 & 13 \\
\hline $\begin{array}{l}\text { The Importance of Websites for Organic Agri-Food } \\
\text { Producers }\end{array}$ & $\begin{array}{l}\text { Fernández-Uclés, D.; } \\
\text { Bernal-Jurado, E.; } \\
\text { Mozas-Moral, A.; } \\
\text { Medina-Viruel, M.J. }\end{array}$ & $\begin{array}{l}\text { Econ. Res.-Ekon. } \\
\text { Istraž. }\end{array}$ & 2020 & 14 \\
\hline $\begin{array}{l}\text { Understanding the Role of Purchasing Predictors in } \\
\text { the Consumer's Preferences for PDO Labelled Honey }\end{array}$ & $\begin{array}{l}\text { Di Vita, G.; Pippinato, L.; } \\
\text { Blanc, S.; Zanchini, R.; } \\
\text { Mosso, A.; Brun, F. }\end{array}$ & $\begin{array}{l}\text { J. Food Prod. } \\
\text { Mark. }\end{array}$ & 2021 & 1 \\
\hline $\begin{array}{l}\text { Generation X versus Millennials Communication } \\
\text { Behaviour on Social Media When Purchasing Food } \\
\text { versus Tourist Services }\end{array}$ & $\begin{array}{l}\text { Dabija, D.-C.; Bejan, B.M.; } \\
\text { Tipi, N. }\end{array}$ & $\begin{array}{l}\text { E+M Ekon. } \\
\text { Manag. }\end{array}$ & 2018 & 99 \\
\hline $\begin{array}{l}\text { EU Quality Label vs Organic Food Products: A } \\
\text { Multigroup Structural Equation Modeling to Assess } \\
\text { Consumers' Intention to Buy in Light of Sustainable } \\
\text { Motives }\end{array}$ & De Canio, F.; Martinelli, E. & Food Res. Int. & 2021 & 16 \\
\hline $\begin{array}{l}\text { Food tourism and regional development: A } \\
\text { systematic literature review }\end{array}$ & $\begin{array}{l}\text { Rachão, S.; Breda, Z.; } \\
\text { Fernandes, C.; Joukes, V. }\end{array}$ & $\begin{array}{l}\text { Eur. J. of Tourism } \\
\text { Research }\end{array}$ & 2019 & 68 \\
\hline $\begin{array}{l}\text { Social media and consumer buying behavior decision: } \\
\text { what entrepreneurs should know? }\end{array}$ & $\begin{array}{l}\text { Palalic, R.; Ramadani, V.; } \\
\quad \text { Mariam Gilani, S.; } \\
\text { Gërguri-Rashiti, S.; Dana, L. }\end{array}$ & Mgmt. Decision & 2021 & 24 \\
\hline $\begin{array}{l}\text { Online Shopping: Factors That Affect Consumer } \\
\text { Purchasing Behaviour }\end{array}$ & $\begin{array}{l}\text { Bucko, J.; Kakalejčík, L.; } \\
\text { Ferencová, M. }\end{array}$ & $\begin{array}{l}\text { Cogent bus. } \\
\text { manag. }\end{array}$ & 2018 & 56 \\
\hline $\begin{array}{l}\text { Expanding the PGI Certification Scheme as a } \\
\text { Marketing Tool in the Olive Oil Industry: A } \\
\text { Perspective on Consumer Behavior }\end{array}$ & $\begin{array}{l}\text { Di Vita, G.; Cavallo, C.; } \\
\text { Del Giudice, T.; Pergamo, R.; } \\
\text { Cicia, G.; D'Amico, M. }\end{array}$ & Br. Food J. & 2021 & 3 \\
\hline $\begin{array}{l}\text { Rural Cooperatives in the Digital Age: An Analysis of } \\
\text { the Internet Presence and Degree of Maturity of } \\
\text { Agri-Food Cooperatives' e-Commerce }\end{array}$ & $\begin{array}{c}\text { Cristobal-Fransi, E.; } \\
\text { Montegut-Salla, Y.; } \\
\text { Ferrer-Rosell, B.; Daries, N. }\end{array}$ & J. Rural Stud. & 2020 & 46 \\
\hline $\begin{array}{l}\text { A Study on Agrifood Purchase Decision-making and } \\
\text { Online Channel Selection according to Consumer } \\
\text { Characteristics, Perceived Risks, and Eating Lifestyles }\end{array}$ & Lee, M.K.; Park, S.H.; Kim, Y.J. & $\begin{array}{l}\text { Asia-Pacific j. of } \\
\text { Bus. Venturing } \\
\quad \text { and } \\
\text { Entrepreneurship. }\end{array}$ & 2021 & 4 \\
\hline $\begin{array}{l}\text { Protected Designation of Origin (PDO), Protected } \\
\text { Geographical Indication (PGI) and Traditional } \\
\text { Speciality Guaranteed (TSG): A Bibiliometric Analysis }\end{array}$ & Dias, C.; Mendes, L. & Food Res. Int. & 2018 & 68 \\
\hline $\begin{array}{l}\text { Understanding the Real-World Impact of } \\
\text { Geographical Indications: A Critical Review of the } \\
\text { Empirical Economic Literature }\end{array}$ & $\begin{array}{l}\text { Török, Á.; Jantyik, L.; } \\
\text { Maró, Z. M.; Moir, H. V. J. }\end{array}$ & Sustainability & 2020 & 14 \\
\hline $\begin{array}{l}\text { The importance of "origin" for online agrifood } \\
\text { products }\end{array}$ & $\begin{array}{l}\text { Scuderi, A.; Sturiale, L.; } \\
\text { Timpanaro, G. }\end{array}$ & $\begin{array}{l}\text { Quality-Access } \\
\text { to Success }\end{array}$ & 2015 & 16 \\
\hline $\begin{array}{l}\text { Geographical Indications, Public Goods, and } \\
\text { Sustainable Development: The Roles of Actors' } \\
\text { Strategies and Public Policies }\end{array}$ & $\begin{array}{l}\text { Belletti, G.; Marescotti, A.; } \\
\text { Touzard, J.-M. }\end{array}$ & World Dev. & 2017 & 211 \\
\hline $\begin{array}{l}\text { Product versus Region of Origin: Which Wins in } \\
\text { Consumer Persuasion? }\end{array}$ & Luceri, B.; Latusi, S.; Zerbini, C. & Br. Food J. & 2016 & 30 \\
\hline $\begin{array}{l}\text { Importance of Regional and Traditional EU Quality } \\
\text { Schemes in Young Consumer Food Purchasing } \\
\text { Decisions }\end{array}$ & $\begin{array}{c}\text { Angowski, M.; } \\
\text { Jarosz-Angowska, A. }\end{array}$ & Eur. Res. Stud. & 2020 & 1 \\
\hline
\end{tabular}


Table 4. Cont.

\begin{tabular}{|c|c|c|c|c|}
\hline Title & Authors & $\begin{array}{c}\text { Journal } \\
\text { of Publication }\end{array}$ & $\begin{array}{l}\text { Publication } \\
\text { Year }\end{array}$ & $\begin{array}{c}\text { Total } \\
\text { Citations * }\end{array}$ \\
\hline $\begin{array}{l}\text { A Study on Consumer Characteristics According to } \\
\text { Social Media Use Clusters When Purchasing } \\
\text { Agri-food Online }\end{array}$ & Lee, M.K.; Park, S.H.; Kim, Y.J. & $\begin{array}{l}\text { Asia-Pacific j. of } \\
\text { Bus. Venturing } \\
\quad \text { and } \\
\text { Entrepreneurship. }\end{array}$ & 2021 & $\mathrm{~N} / \mathrm{A}$ \\
\hline $\begin{array}{l}\text { Estimating the Market Share and Price Premium of GI } \\
\text { Foods-the Case of the Hungarian Food Discounters }\end{array}$ & Jantyik, L.; Török, Á. & Sustainability & 2020 & 10 \\
\hline $\begin{array}{l}\text { Consumers' Awareness of the EU's Protected } \\
\text { Designations of Origin Logo }\end{array}$ & Goudis, A.; Skuras, D. & Br. Food J. & 2021 & 4 \\
\hline $\begin{array}{l}\text { The Role of Intrinsic and Extrinsic Characteristics of } \\
\text { Honey for Italian Millennial Consumers }\end{array}$ & $\begin{array}{l}\text { Blanc, S.; Zanchini, R.; } \\
\text { Di Vita, G.; Brun, F. }\end{array}$ & Br. Food J. & 2021 & 3 \\
\hline $\begin{array}{l}\text { Consumer Preferences Regarding National and EU } \\
\text { Quality Labels for Cheese, Ham and Honey: The Case } \\
\text { of Slovenia }\end{array}$ & $\begin{array}{l}\text { Kos Skubic, M.; Erjavec, K.; } \\
\text { Klopčič, M. }\end{array}$ & Br. Food J. & 2018 & 22 \\
\hline $\begin{array}{l}\text { Social Marketing: A New Marketing Tool for the Food } \\
\text { Sector }\end{array}$ & Elghannam, A.; Mesías, F. J. & $\begin{array}{c}\text { Advances in } \\
\text { Business Strategy } \\
\text { and Competitive } \\
\text { Advantage }\end{array}$ & 2017 & 1 \\
\hline
\end{tabular}

* Total citations in Google Scholar on 20 January 2022. N/A if no citation was reported.

\subsection{Perception about Certified Agri-Food Products}

To obtain market success, products must benefit from a positive overall image among target segments, exhibiting a proper added value and/or providing certain qualities that meet or exceed consumers' expectations [5,17]. Consumers are regarded as a subject more interested in the symbolic or cultural value of certified agri-food products than in their intrinsic functions and utilities [18]. Consumers are considered active players in the market, where they exercise their freedom to move in search of products, but also gain experiences through which they can express their identity [5]. Looking for options to fulfill their expectations and desires, consumers are looking for food quality in terms of product origin, uniqueness, respect for the environment, animal welfare, traditional manufacturing process, taste, providing growth opportunities for small businesses operating in the niche market, the so-called "restricted food", a term that refers to local, certified foods [19]. Other papers [20-22] reflect that agri-food products certified with quality schemes are perceived positively by consumers, as they contribute to improving their health condition, their quality of life, strengthening them and ensuring that with increasing age consumers are still fit. As regards the geographical delimitations, consumers from southern European regions tend to associate more often the term "traditional food" with their culture or history [23]. Agri-food products are consumed on some typical occasions, like on certain holidays and/or seasons, knowledge about that being generally transmitted from one generation to another. Such products are usually manufactured precisely after some certain procedures, being part of the gastronomic heritage of a region or an ethnic group [19], with little or no processing/handling of the original receipt and known for its sensory properties. Furthermore, these products are often associated with a clear delimited geographical area [19]. On the other hand, consumers from central and northern Europe tend to focus mainly on practical issues, such as convenience, health, or the ease and speed of purchasing food [24]. Some consumers consider PDO/PGI labels to be organic, while every second consumers are unsure whether PDO/PGI certified foods are produced without fertilizers and other chemicals $[25,26]$.

\subsection{Preference, Recognition, and Willingness to Pay for Certified Agri-Food Products}

The recent literature indicates a renewed consumer interest in certified agri-food products $[19,27]$. A concern about consumers' perception of certified products is the willingness to pay higher prices than for the non-certified alternatives [28]. These consumers realize that "origin" cannot be always considered a determining factor in consumer choices com- 
pared to cost, safety, and nutrition [29]. The concepts that help explain the correlation between quality labels and willingness to pay depend on factors such as the geographical area investigated, the consumer's residence concerning the production area, consumer demographics, GI label awareness, and product type [29]. At the same time, consumers who know the region to which the certified products refer or feel a certain attachment towards them, tend to be more optimistic about the products labeled PDO/PGI/TSG, thus also exerting a higher willingness of paying even a price premium [30-32]. Because consumers identify certified products with customs and heritage passed down from generation to generation, traditions cannot be exported. These certified products outside their "area of influence" may not have the emotional attachment of experience $[31,33]$. Studies measuring the awareness and recognition of quality labels among European consumers conclude that consumers from Sweden, Denmark, Finland, and the Netherlands, but also France, Italy, Spain, Greece, Portugal have a higher likelihood of recognizing quality labels and their $\log 0 \mathrm{~s}[34,35]$. This is due to the collaborative activities between European producers, which target consumers in these countries.

\subsection{Purchasing and Consumption Behavior of Certified Agri-Food Products}

The reviewed studies set out the different concepts that explain consumers' motivations to buy traditionally produced agri-food products, certified with quality schemes. Regarding the decision to purchase certified agri-food products by young consumers, while recent studies reveal a relatively small significance of EU quality schemes in food purchasing decisions taken by young consumers $[36,37]$. Young consumer behavior is strongly influenced by globalization, social media, online behavior, and current trends, as they frequently do not differentiate between quality schemes such as PDO, PGI, and TSG [37]. Young consumers' most important determinants of food choice are product prices, freshness, and shelf life of products, but also convenience [33,37]. Consumers attribute a higher value to a PDO label than to a PGI. The preference for buying the PDO label over the PGI one might be explained by the fact that consumers tend to perceive $\mathrm{PDO}$ as a certification that firmly guarantees the production, processing, and preparation of agri-food products in a well-established geographical area [38,39]. Perceived quality associated with extrinsic attributes (such as quality, brands, labels, design, information on use and benefits, authenticity, commitment to the environment, cultural ties) significantly influences the purchasing of certified agri-food products [22,27]. Older consumers with higher education and above-average incomes show an increased preference for certified products with quality schemes [21].

\subsection{Online Purchasing of Certified Agri-Food Products}

Information and Communication Technology (ICT) has developed as the new frontier for organizations in various industries, as well as agriculture, thus being considered a strategy that will bridge the gap between producers and consumers [40,41]. Therefore, the agri-food sector needs to increase its competitiveness, and be able to respond quickly to the ever-changing consumer needs and desires, thus satisfying him/her and properly communicating the extrinsic and intrinsic added values of certified agri-food products through online stores developed for modern customers [42,43]. Social networks represent a channel from which consumers take relevant information for their next purchase decisions; consumers are often more influenced and trust strangers and online influencers than official representative of companies [44,45]. The shopping decision is strongly influenced by online reviews and recommendations from blogs, forums and/or social networks [46]. Agricultural cooperatives take information about consumers, which they integrate into their communication strategies, and inform customers about certified agri-food products [47-49]. Such organizations are usually aware of the importance that the territory of origin (physical, sensory, and cultural) of certified agri-food products and production techniques plays for consumers, thus representing strong values that might trigger consumers preferences [42]. Furthermore, agricultural cooperatives must go beyond their traditional presence, thus 
encouraging online interaction and collaboration, connectivity, and giving consumers the possibility to find and share information and gain knowledge about certified agrifood products [50]. For instance, cooperatives that produce and sell olive oil, fruit, and wine are more recently aware of the importance that their online communication plays for consumers purchase intention [50-52]. Online shopping causes consumers to behave differently concerning the intangibility of the product $[53,54]$.

While in on-site shopping, the information comes from the sensory examination of the product, online shopping is determined by other factors: the customer's intention to buy, the influence of friends and family, consumer personality, but also knowledge and curiosity $[53,55]$. The attitude of buying online food products is also improved by extrinsic factors, such as the quality of the website (design, content, and navigation), product availability, ease of use, which positively affect the purchase intention [54,56-58]. Consumers who purchase certified agri-food products online would like to have access to information on the environmental impact and sustainability of products, in addition to the unique properties and characteristics of agri-food products [53,59-61].

The aspects and findings presented in the previous sub-sections of the Results are summarized in Table 5.

Table 5. Overview of representative papers according to different assessment criteria.

\begin{tabular}{|c|c|c|c|c|c|c|c|c|c|c|c|c|c|}
\hline \multirow[b]{2}{*}{$\begin{array}{l}\text { Publication } \\
\text { Year }\end{array}$} & \multirow[b]{2}{*}{ Authors } & \multicolumn{3}{|c|}{ Type of Paper } & \multicolumn{2}{|c|}{ Type of Study } & \multicolumn{3}{|c|}{ Quality Schemes } & \multicolumn{4}{|c|}{ Consumer Concepts } \\
\hline & & 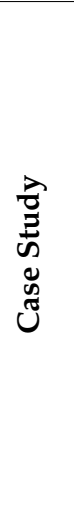 & 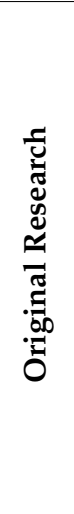 & 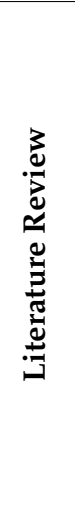 & 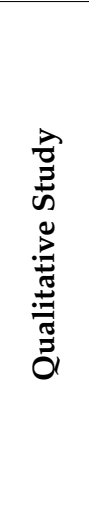 & 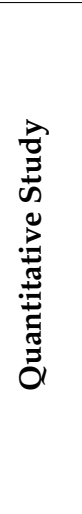 & @ి & $\overline{0}$ & $\bigcup_{\mathscr{H}}$ & 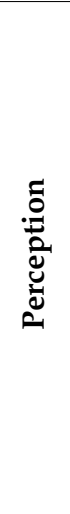 & 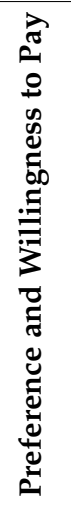 & 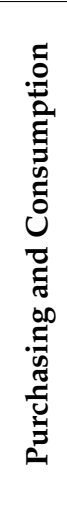 & 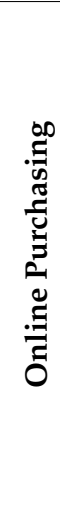 \\
\hline 2015 & $\begin{array}{l}\text { Scuderi, A.; Sturiale, L.; } \\
\text { Timpanaro, G. }\end{array}$ & - & $\checkmark$ & - & $\checkmark$ & - & $\checkmark$ & $\checkmark$ & - & - & - & $\checkmark$ & - \\
\hline 2016 & $\begin{array}{l}\text { Grunert, K.G.; } \\
\text { Aachmann, K. }\end{array}$ & - & - & $\checkmark$ & $\checkmark$ & - & $\checkmark$ & $\checkmark$ & $\checkmark$ & $\checkmark$ & $\checkmark$ & - & - \\
\hline 2016 & $\begin{array}{l}\text { Luceri, B.; Latusi, S.; } \\
\text { Zerbini, C. }\end{array}$ & - & $\checkmark$ & - & - & $\checkmark$ & $\checkmark$ & $\checkmark$ & - & $\checkmark$ & $\checkmark$ & - & - \\
\hline 2017 & Garavaglia, C.; Mariani, P. & - & $\checkmark$ & - & - & $\checkmark$ & $\checkmark$ & - & - & - & $\checkmark$ & - & - \\
\hline 2017 & $\begin{array}{c}\text { Martínez, A.A.; } \\
\text { Fernández-Poyatos, M.D. }\end{array}$ & - & $\checkmark$ & - & $\checkmark$ & - & $\checkmark$ & $\checkmark$ & - & - & - & $\checkmark$ & - \\
\hline 2017 & $\begin{array}{l}\text { Martinelli, E.; De Canio, F.; } \\
\text { Marchi, G.; Nardin, G. }\end{array}$ & - & $\checkmark$ & - & - & $\checkmark$ & $\checkmark$ & $\checkmark$ & - & $\checkmark$ & - & - & - \\
\hline 2017 & $\begin{array}{l}\text { Belletti, G.; Marescotti, A.; } \\
\text { Touzard, J.-M. }\end{array}$ & $\checkmark$ & - & - & $\checkmark$ & - & $\checkmark$ & $\checkmark$ & $\checkmark$ & $\checkmark$ & $\checkmark$ & $\checkmark$ & - \\
\hline 2017 & Elghannam, A.; Mesías, F. J. & - & $\checkmark$ & - & $\checkmark$ & - & $\checkmark$ & $\checkmark$ & $\checkmark$ & - & - & - & - \\
\hline 2018 & $\begin{array}{c}\text { Dabija, D.-C.; Bejan, B.M.; } \\
\text { Tipi, N. }\end{array}$ & - & $\checkmark$ & - & - & $\checkmark$ & - & - & - & - & - & - & - \\
\hline 2018 & $\begin{array}{l}\text { Bucko, J.; Kakalejčík, L.; } \\
\text { Ferencová, M. }\end{array}$ & - & $\checkmark$ & - & - & $\checkmark$ & - & - & - & $\checkmark$ & $\checkmark$ & - & - \\
\hline 2018 & Dias, C.; Mendes, L. & - & - & $\checkmark$ & $\checkmark$ & - & $\checkmark$ & $\checkmark$ & $\checkmark$ & $\checkmark$ & $\checkmark$ & $\checkmark$ & - \\
\hline 2018 & $\begin{array}{c}\text { Kos Skubic, M.; Erjavec, K.; } \\
\text { Klopčič, M. }\end{array}$ & - & $\checkmark$ & - & - & $\checkmark$ & $\checkmark$ & $\checkmark$ & - & $\checkmark$ & $\checkmark$ & - & - \\
\hline 2019 & Martinelli, E.; De Canio, F. & $\checkmark$ & - & - & - & $\checkmark$ & $\checkmark$ & $\checkmark$ & - & - & $\checkmark$ & $\checkmark$ & - \\
\hline 2019 & $\begin{array}{l}\text { Tham, K. W.; Dastane, O.; } \\
\text { Johari, Z.; Ismail, N.B. }\end{array}$ & - & $\checkmark$ & - & - & $\checkmark$ & - & - & - & - & - & - & $\checkmark$ \\
\hline
\end{tabular}


Table 5. Cont.

\begin{tabular}{|c|c|c|c|c|c|c|c|c|c|c|c|c|c|}
\hline \multirow[b]{2}{*}{$\begin{array}{l}\text { Publication } \\
\text { Year }\end{array}$} & \multirow[b]{2}{*}{ Authors } & \multicolumn{3}{|c|}{ Type of Paper } & \multicolumn{2}{|c|}{ Type of Study } & \multicolumn{3}{|c|}{ Quality Schemes } & \multicolumn{4}{|c|}{ Consumer Concepts } \\
\hline & & 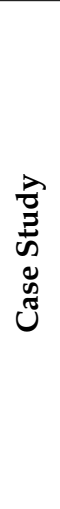 & 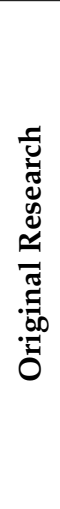 & 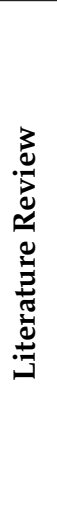 & 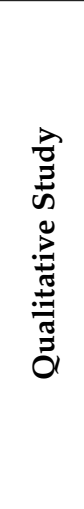 & 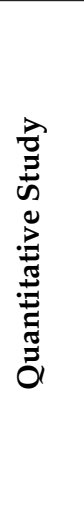 & @ & U̦ & $\underset{W}{W}$ & : & 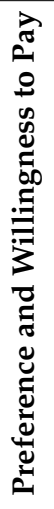 & 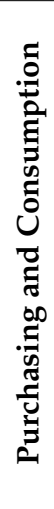 & 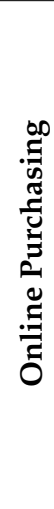 \\
\hline 2019 & $\begin{array}{c}\text { Oleksiuk, I.; } \\
\text { Werenowska, A. }\end{array}$ & - & $\checkmark$ & - & - & $\checkmark$ & $\checkmark$ & $\checkmark$ & $\checkmark$ & $\checkmark$ & $\checkmark$ & $\checkmark$ & - \\
\hline 2019 & $\begin{array}{l}\text { Rachão, S.; Breda, Z.; } \\
\text { Fernandes, C.; Joukes, V. } \\
\text { Robina-Ramírez, R.; }\end{array}$ & - & - & $\checkmark$ & - & $\checkmark$ & $\checkmark$ & $\checkmark$ & - & $\checkmark$ & $\checkmark$ & $\checkmark$ & - \\
\hline 2020 & $\begin{array}{l}\text { Chamorro-Mera, A.; } \\
\text { Moreno-Luna, L. }\end{array}$ & $\checkmark$ & - & - & - & $\checkmark$ & - & - & - & - & $\checkmark$ & - & $\checkmark$ \\
\hline 2020 & $\begin{array}{l}\text { Fernández-Uclés, D.; } \\
\text { Bernal-Jurado, E.; } \\
\text { Mozas-Moral, A.; } \\
\text { Medina-Viruel, M.J. } \\
\text { Cristobal-Fransi, E.; }\end{array}$ & - & $\checkmark$ & - & $\checkmark$ & - & - & - & - & - & - & - & $\checkmark$ \\
\hline 2020 & $\begin{array}{l}\text { Montegut-Salla, Y.; } \\
\text { Ferrer-Rosell, B.; Daries, N. }\end{array}$ & - & $\checkmark$ & - & $\checkmark$ & - & $\checkmark$ & $\checkmark$ & $\checkmark$ & - & - & - & $\checkmark$ \\
\hline 2020 & $\begin{array}{c}\text { Török, Á.; Jantyik, L.; } \\
\text { Maró, Z. M.; Moir, H. V. J. }\end{array}$ & - & - & $\checkmark$ & $\checkmark$ & - & $\checkmark$ & $\checkmark$ & $\checkmark$ & $\checkmark$ & $\checkmark$ & $\checkmark$ & $\checkmark$ \\
\hline 2020 & $\begin{array}{c}\text { Angowski, M.; } \\
\text { Jarosz-Angowska, A. }\end{array}$ & - & $\checkmark$ & - & - & $\checkmark$ & $\checkmark$ & $\checkmark$ & $\checkmark$ & $\checkmark$ & $\checkmark$ & $\checkmark$ & - \\
\hline 2020 & $\begin{array}{l}\text { Jantyik, L.; Török, Á. } \\
\text { Savelli, E.; Bravi, L.; }\end{array}$ & - & $\checkmark$ & - & - & $\checkmark$ & $\checkmark$ & $\checkmark$ & $\checkmark$ & - & $\checkmark$ & - & - \\
\hline 2021 & $\begin{array}{c}\text { Francioni, B.; Murmura, F.; } \\
\text { Pencarelli, T. }\end{array}$ & - & $\checkmark$ & - & - & $\checkmark$ & $\checkmark$ & - & - & $\checkmark$ & - & - & - \\
\hline 2021 & $\begin{array}{l}\text { Skalkos, D.; Kosma, I. S.; } \\
\text { Vasiliou, A.; Guine, R. P. F. } \\
\text { Di Vita, G.; Pippinato, L.; }\end{array}$ & - & $\checkmark$ & - & - & $\checkmark$ & $\checkmark$ & $\checkmark$ & $\checkmark$ & $\checkmark$ & $\checkmark$ & $\checkmark$ & - \\
\hline 2021 & $\begin{array}{l}\text { Blanc, S.; Zanchini, R.; } \\
\text { Mosso, A.; Brun, F. }\end{array}$ & - & $\checkmark$ & - & - & $\checkmark$ & $\checkmark$ & - & - & - & $\checkmark$ & - & - \\
\hline 2021 & $\begin{array}{l}\text { De Canio, F.; Martinelli, E. } \\
\text { Palalic, R.; Ramadani, V.; }\end{array}$ & - & $\checkmark$ & - & - & $\checkmark$ & $\checkmark$ & $\checkmark$ & - & - & $\checkmark$ & - & - \\
\hline 2021 & $\begin{array}{c}\text { Mariam Gilani, S.; } \\
\text { Gërguri-Rashiti, S.; Dana, L. } \\
\text { Di Vita, G.; Cavallo, C.; }\end{array}$ & - & $\checkmark$ & - & - & $\checkmark$ & - & - & - & - & - & - & $\checkmark$ \\
\hline 2021 & $\begin{array}{l}\text { Del Giudice, T.; Pergamo, R.; } \\
\text { Cicia, G.; D’Amico, M. }\end{array}$ & - & $\checkmark$ & - & - & $\checkmark$ & - & $\checkmark$ & - & - & - & $\checkmark$ & - \\
\hline 2021 & $\begin{array}{l}\text { Lee, M.K.; Park, S.H.; } \\
\text { Kim, Y.J. }\end{array}$ & - & $\checkmark$ & - & - & $\checkmark$ & $\checkmark$ & $\checkmark$ & $\checkmark$ & - & - & $\checkmark$ & $\checkmark$ \\
\hline 2021 & $\begin{array}{l}\text { Lee, M.K.; Park, S.H.; } \\
\text { Kim, Y.J. }\end{array}$ & - & $\checkmark$ & - & - & $\checkmark$ & $\checkmark$ & $\checkmark$ & $\checkmark$ & $\checkmark$ & $\checkmark$ & - & - \\
\hline 2021 & Goudis, A.; Skuras, D. & - & $\checkmark$ & - & - & $\checkmark$ & $\checkmark$ & $\checkmark$ & - & $\checkmark$ & - & - & - \\
\hline 2021 & $\begin{array}{l}\text { Blanc, S.; Zanchini, R.; } \\
\text { Di Vita, G.; Brun, F. }\end{array}$ & - & $\checkmark$ & - & - & $\checkmark$ & - & - & - & $\checkmark$ & - & - & - \\
\hline
\end{tabular}




\section{Discussion}

Even though the studies covered use various methodologies and provide contradictory results, this systematic review reveals several common features that stand in line with previous research [16,62-65], indicating that the understanding about certified agri-food products are mixed. In line with previous studies, were identified consumers that consider that the food quality is not verified $[25,26]$. Thus, there are consumers that trust the meaning of these certifications and choose to buy a more traditional healthy food product $[20,21,23,24,35,66]$.

The "area of influence" is one of the most crucial factors for selling certified products; the emotional attachment of experience that each product comes with could help consumers refine the natural taste. This represents a major objective for certified product, to keep its taste, smell, and/or nutritional qualities. Several studies $[19,23,24,67]$ showed that the culture of the geographical delimitations influences the perceptions about certified agri-food products. The certified agri-food products have an advantage for consumers who know the product's region, so the certification proves that the product is created strictly in that region it kept its originality. In southern Europe tend to associate them with the terms "traditional food" and "brand-name"; this is seen more often in combination with the concepts, culture, or even history, heritage, and customs passed down from one generation to another. From the past, we can learn about the types of food that our ancestors were eating without any chemicals for growing. The central and northern Europe regions tend to focus more on the practical benefits of product convenience, health, or purchase access in another area of Europe.

The "origin" of the product is not always the determining factor in consumer choices. Many consumers consider that the nutritional aspects, cost, and safety sometimes come first when choosing the right product for their needs. Education, income, and globalization are factors that influence the consumption behavior of certified agri-food products. Consumers with above-average income and higher education show more interest in the certified product with quality schemes. On the other hand, we have the "young generation" the consumers strongly influenced by globalization and the current trends. They do not differentiate between certified agri-food products. The most critical factors that determine the young consumer to purchase are nutritional factors, freshness, and price. Young consumers caring about their health choose the most suitable product to pay as economical as possible and get the best outcome for their budget $[21,27,36,37,68]$.

In both the on-site and online environment, we can find different factors that help the consumers choose the right product for their needs. In the on-site situation, we see distinct influences from extrinsic and intrinsic influential factors. Most of the time, the extrinsic factors that influence the purchasing decision of the certified agri-food product are the purchasing environment around the products, such as the shelf arrangement and even the type of store. Regarding intrinsic factors, we have the smell, package, nutritional information about the product, the price, the colors. On the other hand, in the Online, we have a different set of influential factors that are much more of a technical nature, such as the User Experience (UX) of the website, the speed, the colors, and most important aspects like the delivery duration, information about the product (description of the quality schemes and logos, area of production, etc.), the online support of the website [47-49,51-54]. These are some of the factors that help in choosing the right product online. One of the essential elements that online shopping offers to customers is package delivery. In 2022, the world is starting to change towards a new era of packaging where cheap and efficient is not enough anymore. A package should be ergonomic, safe, recyclable, and, most important, a storyteller for the brand and its products.

During the COVID-19 pandemic, consumer preferences have leant toward certified foods whose origin is known. Thus, the PDO label begins to become a choice for consumers concerned about their health and a diet that supports their immune system [66,69-71]. Moreover, the traditional shopping system has been altered, so consumers tend to buy healthy food online [72,73]. Although the price of certified agri-food was higher, there is a preference for certified food products with quality schemes among the consumers [71,74]. 
Also, by consuming products of this type-of controlled origin, certified by the EU, the health can be maintained, and the body's immunity can be increased. In COVID-19 and pandemic restrictions, the consumers' food must be safe when human movement is restricted due to regulations. Thus, they must have an appropriate quality, respectively, to have a controlled origin $[66,69,70]$.

\section{Conclusions}

In 2021, perception of success in the food market is about exceeding the consumer expectations, providing them with much better quality than they have asked, providing package, information, and a premium feeling about the product. These details help to reach a positive opinion about the certified agri-food products. EU quality labels were introduced as a consumer decision-making tool. Still, they are also a way of controlling food, as the logo's appearance ensures that the product can be traced back to a specific manufacturing area and to a specified know-how process. EU quality schemes can thereby potentially reduce confusion about food purchases, assuring the customer of the certified agri-food products' uniqueness and nutritional qualities. The on-site and online environment is trying to draw attention to more specific aspects that can bring quality to food products, such as certifications, animal welfare standards, and respect for the environment. In both climates, one can highlight different types of influence trying to make the final customers self-generate the mindset that "eating healthy" might be understood as "living healthy". The influential factors are all about sharing as much quality information as possible with the customer: nutritional information, region of production/origin, price, package, colors. The "young generation" is powerfully influenced by globalization, social media, Internet, green behavior, and current trends, through which they can be educated about the importance of consuming quality products, what effect it has over their body in the long term, and what conduct they should adopt to have a healthier life in a healthfuller community.

\subsection{Implications for Market Participants and Public Institutions}

Nationally sustained by different post-COVID-19 strategies, the PDO, PGI, and TSG certifications would have, as a result, the increased level of health of the population. One of the solutions would be to encourage local producers to apply for this certification. The food products with the certification PDO, PGI, TSG have a better impact on consumers' health because of their pure ingredients and the lack of artificial chemicals. Consuming a healthy, non-altered, and natural product is one of the leading health benefits of these products. Moreover, these review results are helpful to different government agencies and companies to improve their promotion strategies towards these types of certifications that verify quality and tradition.

\subsection{Limitations and Further Directions of Research}

There are certain limitations to our research. The search strategy may have omitted pertinent material that brings the possibility that removed articles include information that could affect our conclusions. Given the prevalence of the PGI and PDO certification schemes, more research into the TSG quality certification scheme is required. More research is necessary on consumer behavior regarding PGI, PDO, and TSG food products, considering the variances between nations or areas. Since there is a focus on examining certified products susceptible to some form of agro-industrial production, such as meat, cheese, wine, and olive oil, perception and consumption behavior of certified fruit or vegetable varieties could provide a viable path for further directions of research. In addition, more research is needed to link certified food products with the European quality schemes to the health benefits they can provide in pandemic times, relying on educating consumers about the value and benefits of these certified products with quality schemes.

Author Contributions: Conceptualization, A.-I.G. and C.B.P.; methodology, A.-I.G. and C.B.P.; validation, C.B.P., D.-C.D. and M.F.; formal analysis, A.-I.G.; investigation, A.-I.G.; resources, A.-I.G. and C.B.P.; writing—original draft preparation, A.-I.G.; C.B.P.; D.-C.D.; writing—review and editing, 
A.-I.G.; C.B.P., D.-C.D. and M.F.; visualization, C.B.P.; D.-C.D. and M.F.; supervision, C.B.P. and

D.-C.D. All authors have read and agreed to the published version of the manuscript.

Funding: This research received no external funding.

Institutional Review Board Statement: Not applicable.

Informed Consent Statement: Not applicable.

Data Availability Statement: Not applicable.

Acknowledgments: The authors would like to express their gratitude to all reviewers who provided helpful suggestions for improving our work.

Conflicts of Interest: The authors declare no conflict of interest.

\section{References}

1. Di Giacomo, M.G.G. The relationship between Food-Agriculture-Environment compared with the new Common Agricultural Policy. AGEI Geotema 2020, 52, 8-17.

2. Vilke, R.; Vidickiene, D.; Gedminaite-Raudone, Z.; Simonaityte, V.; Ribasauskiene, E. Rural Economic Developments and Social Movements: A New Paradigm; Springer Nature: Cham, Switzerland, 2021; ISBN 978-303-071-983-8.

3. Bu, F.; Wang, X. A Smart Agriculture IoT System Based on Deep Reinforcement Learning. Future Gener. Comput. Syst. 2019, 99, 500-507. [CrossRef]

4. Sikora, A. European Green Deal-legal and financial challenges of the climate change. ERA Forum 2021, 21, 681-697. [CrossRef]

5. De Canio, F.; Martinelli, E. EU Quality Label vs Organic Food Products: A Multigroup Structural Equation Modeling to Assess Consumers' Intention to Buy in Light of Sustainable Motives. Food Res. Int. 2021, 139, 109846. [CrossRef] [PubMed]

6. European Green Deal, the Economic, Social and Environmental Sustainability, a Priority for the PDO PGI Supply Chains Available online: http:/ / www.lifettgg.eu/en/2020/12/16/the-economic-social-and-environmental-sustainability-a-priorityfor-the-pdo-pgi-supply-chains/ (accessed on 23 September 2021).

7. European Commission. Quality Schemes Explained. Available online: https:/ / ec.europa.eu/info/food-farming-fisheries/foodsafety-and-quality/certification/quality-labels/quality-schemes-explained/ (accessed on 23 September 2021).

8. Gellynck, X.; Kühne, B. Innovation and Collaboration in Traditional Food Chain Networks. J. Chain Netw. Sci. 2008, 8, 121-129. [CrossRef]

9. Carbone, A.; Caswell, J.; Galli, F.; Sorrentino, A. The Performance of Protected Designations of Origin: An Ex Post Multi-Criteria Assessment of the Italian Cheese and Olive Oil Sectors. J. Agric. Food Ind. Organ. 2014, 12, 121-140. [CrossRef]

10. Regulamentul (UE) nr. 1151/2012 al Parlamentului European și al Consiliului din 21 Noiembrie 2012 Privind Sistemele din Domeniul Calității Produselor Agricole și Alimentare. Available online: https://eur-lex.europa.eu/legal-content/RO/TXT/ ?uri=CELEX\%3A32012R1151 (accessed on 23 September 2021).

11. Cassago, A.L.L.; Artêncio, M.M.; de Moura Engracia Giraldi, J.; Da Costa, F.B. Metabolomics as a Marketing Tool for Geographical Indication Products: A Literature Review. Eur. Food Res. Technol. 2021, 247, 1-17. [CrossRef]

12. Marescotti, A. Typical products and rural development: Who benefits from PDO/PGI recognition. In Proceedings of the Food Quality Products in the Advent of the 21st Century: Production, Demand and Public Policy. 83rd EAAE Seminar, Chania, Greece, 9-10 September 2003; CIHEAM: Chania, Greece, 2003; Volume 4.

13. Mancini, M.; Menozzi, D.; Donati, M.; Biasini, B.; Veneziani, M.; Arfini, F. Producers' and Consumers' Perception of the Sustainability of Short Food Supply Chains: The Case of Parmigiano Reggiano PDO. Sustainability 2019, 11, 721. [CrossRef]

14. European Commission. The EU Geographical Indications Register. Available online: https://ec.europa.eu/info/food-farmingfisheries/food-safety-and-quality/certification/quality-labels/geographical-indications-register/ (accessed on 14 January 2022).

15. Campos, S.; Doxey, J.; Hammond, D. Nutrition Labels on Pre-Packaged Foods: A Systematic Review. Public Health Nutr. 2011, 14, 1496-1506. [CrossRef]

16. Olbrich, R.; Jansen, H.C.; Hundt, M. Effects of Pricing Strategies and Product Quality on Private Label and National Brand Performance. J. Retail. Consum. Serv. 2017, 34, 294-301. [CrossRef]

17. Arfini, F.; Bellassen, V. Correction to: Sustainability of European Food Quality Schemes. In Sustainability of European Food Quality Schemes; Springer International Publishing: Cham, Switzerland, 2020; p. C1, ISBN 978-303-027-507-5.

18. Verbeke, W.; Guerrero, L.; Almli, V.L.; Vanhonacker, F.; Hersleth, M. European Consumers' Definition and Perception of Traditional Foods. In Traditional Foods; Springer US: Boston, MA, USA, 2016; pp. 3-16. [CrossRef]

19. Likoudis, Z.; Sdrali, D.; Costarelli, V.; Apostolopoulos, C. Consumers' Intention to Buy Protected Designation of Origin and Protected Geographical Indication Foodstuffs: The Case of Greece: Greek Consumer Behaviour and PDO/PGI. Int. J. Consum. Stud. 2016, 40, 283-289. [CrossRef]

20. Prakash, V. Introduction: The Importance of Traditional and Ethnic Food in the Context of Food Safety, Harmonization, and Regulations. In Regulating Safety of Traditional and Ethnic Foods; Prakash, V., Martín-Belloso, O., Keener, L., Astley, S., Braun, S., McMahon, H., Lelieveld, H., Eds.; Academic Press: Waltham, MA, USA, 2016; pp. 1-6, ISBN 978-012-800-605-4. 
21. Belletti, G.; Marescotti, A.; Touzard, J.-M. Geographical Indications, Public Goods, and Sustainable Development: The Roles of Actors' Strategies and Public Policies. World Dev. 2017, 98, 45-57. [CrossRef]

22. Barska, A.; Wojciechowska-Solis, J. Traditional and Regional Food as Seen by Consumers-Research Results: The Case of Poland. Br. Food J. 2018, 120, 1994-2004. [CrossRef]

23. Martínez, A.A.; Fernández-Poyatos, M.D. Gastronomy as a tourism resource in the province of Alicante. Int. J. Sci. Manag. Tour. 2017, 3, 25-45.

24. Fandos-Herrera, C. Exploring the Mediating Role of Trust in Food Products with Protected Designation of Origin. The Case of 'Jamón de Teruel'. Span. J. Agric. Res. 2016, 14, 2. [CrossRef]

25. Magagnoli, S. The Construction of Planetary Taste; Routledge: London, UK, 2021; pp. 173-185, ISBN 978-100-305-441-2.

26. Martinelli, E.; De Canio, F. Premium Private Labels Products: Drivers of Consumers' Intention to Buy. Int. J. Bus. Manag. 2019, 14, 36. [CrossRef]

27. Jantyik, L.; Török, Á. Estimating the Market Share and Price Premium of GI Foods—the Case of the Hungarian Food Discounters Sustainability 2020, 12, 1094. [CrossRef]

28. Garavaglia, C.; Mariani, P. How Much Do Consumers Value Protected Designation of Origin Certifications? Estimates of Willingness to Pay for PDO Dry-Cured Ham in Italy: How Much Do Consumers Value Protected Designation of Origin Certifications? Agribusiness 2017, 33, 403-423. [CrossRef]

29. Luceri, B.; Latusi, S.; Zerbini, C. Product versus Region of Origin: Which Wins in Consumer Persuasion? Br. Food J. 2016, 118, 2157-2170. [CrossRef]

30. Balogh, P.; Békési, D.; Gorton, M.; Popp, J.; Lengyel, P. Consumer Willingness to Pay for Traditional Food Products. Food Policy 2016, 61, 176-184. [CrossRef]

31. Muça, E.; Pomianek, I.; Peneva, M. The Role of GI Products or Local Products in the Environment-Consumer Awareness and Preferences in Albania, Bulgaria and Poland. Sustainability 2021, 14, 4. [CrossRef]

32. Russo, V.; Zito, M.; Bilucaglia, M.; Circi, R.; Bellati, M.; Marin, L.E.M.; Catania, E.; Licitra, G. Dairy Products with Certification Marks: The Role of Territoriality and Safety Perception on Intention to Buy. Foods 2021, 10, 2352. [CrossRef]

33. Oleksiuk, I.; Werenowska, A. Promotion of Regional and Traditional Products. Środ. Stud. Polit. 2019, 2, 135-149. [CrossRef]

34. Goudis, A.; Skuras, D. Consumers' Awareness of the EU's Protected Designations of Origin Logo. Br. Food J. 2021, 123, 1-18. [CrossRef]

35. Blanc, S.; Zanchini, R.; Di Vita, G.; Brun, F. The Role of Intrinsic and Extrinsic Characteristics of Honey for Italian Millennial Consumers. Br. Food J. 2021, 123, 2183-2198. [CrossRef]

36. Angowski, M.; Jarosz-Angowska, A. Importance of Regional and Traditional EU Quality Schemes in Young Consumer Food Purchasing Decisions. Eur. Res. Stud. 2020, 23, 916-927. [CrossRef]

37. Martinelli, E.; De Canio, F.; Marchi, G.; Nardin, G. Premium Private Labels and PDO/PGI Products: Effects on Customer Loyalty. In Advances in National Brand and Private Label Marketing; Springer International Publishing: Cham, Switzerland, 2017; pp. 65-72. [CrossRef]

38. Di Vita, G.; Cavallo, C.; Del Giudice, T.; Pergamo, R.; Cicia, G.; D'Amico, M. Expanding the PGI Certification Scheme as a Marketing Tool in the Olive Oil Industry: A Perspective on Consumer Behavior. Br. Food J. 2021, 123, 3841-3856. [CrossRef]

39. Scuderi, A.; Sturiale, L.; Timpanaro, G. The importance of "origin" for online agrifood products. Qual.-Access Success 2015, 16, 260-266.

40. Pegan, G.; Vianelli, D.; de Luca, P. Online Channels and the Country of Origin. In International Marketing Strategy; Springer International Publishing: Cham, Switzerland, 2020; pp. 149-180, ISBN 978-303-033-588-5.

41. Watts, D.C.; Ilbery, B.; Maye, D. Making reconnections in agro-food geography: Alternative systems of food provision. In The Rural; Routledge: London, UK, 2017; pp. 165-184, ISBN 978-131-523-721-3.

42. Lee, M.K.; Park, S.H.; Kim, Y.J. A Study on Agrifood Purchase Decision-making and Online Channel Selection according to Consumer Characteristics, Perceived Risks, and Eating Lifestyles. Asia-Pac. J. Bus. Ventur. Entrep. 2021, 16, 147-159.

43. Lee, M.K.; Park, S.H.; Kim, Y.J. A Study on Consumer Characteristics According to Social Media Use Clusters When Purchasing Agri-food Online. Asia-Pac. J. Bus. Ventur. Entrep. 2021, 16, 195-209.

44. Palalic, R.; Ramadani, V.; Mariam Gilani, S.; Gërguri-Rashiti, S.; Dana, L. Social media and consumer buying behavior decision: What entrepreneurs should know? Manag. Decis. 2021, 59, 1249-1270. [CrossRef]

45. Dabija, D.-C.; Bejan, B.M.; Tipi, N. Generation X versus Millennials Communication Behaviour on Social Media When Purchasing Food versus Tourist Services. E+M Ekon. Manag. 2018, 21, 191-205. [CrossRef]

46. Hofacker, C.F.; Belanche, D. Eight Social Media Challenges for Marketing Managers. Span. J. Mark.-ESIC 2016, 20, 73-80. [CrossRef]

47. Elghannam, A.; Mesías, F.J. Social Marketing: A New Marketing Tool for the Food Sector. In Advances in Business Strategy and Competitive Advantage; IGI Global: Hershey, PA, USA, 2017; pp. 91-106. [CrossRef]

48. Brečić, R.; Tomić Maksan, M.; Đugum, J. The Case of the PDO and PGI Label in the Croation Market. In Proceedings of the 7th International M-Sphere Conference for Multidisciplinarity in Business and Science, Zagreb, Croatia, $24-26$ October 2019.

49. Cristobal-Fransi, E.; Montegut-Salla, Y.; Ferrer-Rosell, B.; Daries, N. Rural Cooperatives in the Digital Age: An Analysis of the Internet Presence and Degree of Maturity of Agri-Food Cooperatives' e-Commerce. J. Rural Stud. 2020, 74, 55-66. [CrossRef] 
50. Bernal-Jurado, E.; Mozas-Moral, A.; Fernández-Uclés, D.; Medina-Viruel, M.J. Online Popularity as a Development Factor for Cooperatives in the Winegrowing Sector. J. Bus. Res. 2021, 123, 79-85. [CrossRef] [PubMed]

51. Karanikolas, P.; Martinez-Gomez, V.; Galli, F.; Prosperi, P.; Hernández, P.A.; Arnalte-Mur, L.; Rivera, M.; Goussios, G.; Fastelli, L.; Oikonomopoulou, E.; et al. Food System Integration of Olive-Oil-Producing Small Farms in Southern Europe. Glob. Food Sec. 2021, 28. [CrossRef]

52. Robina-Ramírez, R.; Chamorro-Mera, A.; Moreno-Luna, L. Organic and Online Attributes for Buying and Selling Agricultural Products in the E-Marketplace in Spain. Electron. Commer. Res. Appl. 2020, 42, 1-12. [CrossRef]

53. Xu, H.; Zhang, K.Z.K.; Zhao, S.J. A dual systems model of online impulse buying. Ind. Manag. Data Syst. 2020, $120,845-861$. [CrossRef]

54. Bucko, J.; Kakalejčík, L.; Ferencová, M. Online Shopping: Factors That Affect Consumer Purchasing Behaviour. Cogent Bus. Manag. 2018, 5, 1535751. [CrossRef]

55. Ariff, M.S.M.; Yan, N.S.; Zakuan, N.; Bahari, A.Z.; Jusoh, A. Web-Based Factors Affecting Online Purchasing Behaviour. IOP Conf. Ser. Mater. Sci. Eng. 2013, 46, 10. [CrossRef]

56. Tham, K.W.; Dastane, O.; Johari, Z.; Ismail, N.B. Perceived Risk Factors Affecting Consumers' Online Shopping Behaviour. J. Asian Financ. Econ. Bus. 2019, 6, 246-260. [CrossRef]

57. Fernández-Uclés, D.; Bernal-Jurado, E.; Mozas-Moral, A.; Medina-Viruel, M.J. The Importance of Websites for Organic Agri-Food Producers. Econ. Res.-Ekon. Istraž. 2020, 33, 2867-2880. [CrossRef]

58. Di Vita, G.; Pippinato, L.; Blanc, S.; Zanchini, R.; Mosso, A.; Brun, F. Understanding the Role of Purchasing Predictors in the Consumer's Preferences for PDO Labelled Honey. J. Food Prod. Mark. 2021, 27, 42-56. [CrossRef]

59. Grunert, K.G.; Aachmann, K. Consumer Reactions to the Use of EU Quality Labels on Food Products: A Review of the Literature Food Control 2016, 59, 178-187. [CrossRef]

60. Teuber, R. Consumers' and Producers' Expectations towards Geographical Indications: Empirical Evidence for a German Case Study. Br. Food J. 2011, 113, 900-918. [CrossRef]

61. González-Azcárate, M.; Cruz Maceín, J.L.; Bardají, I. Why Buying Directly from Producers Is a Valuable Choice? Expanding the Scope of Short Food Supply Chains in Spain. Sustain. Prod. Consum. 2021, 26, 911-920. [CrossRef]

62. Dias, C.; Mendes, L. Protected Designation of Origin (PDO), Protected Geographical Indication (PGI) and Traditional Speciality Guaranteed (TSG): A Bibiliometric Analysis. Food Res. Int. 2018, 103, 492-508. [CrossRef]

63. Rachão, S.; Breda, Z.; Fernandes, C.; Joukes, V. Food tourism and regional development: A systematic literature review. Eur. J. Tour. Res. 2019, 21, 33-49. [CrossRef]

64. Török, Á.; Jantyik, L.; Maró, Z.M.; Moir, H.V.J. Understanding the Real-World Impact of Geographical Indications: A Critical Review of the Empirical Economic Literature. Sustainability 2020, 12, 9434. [CrossRef]

65. Dimitrakopoulou, M.-E.; Vantarakis, A. Does Traceability Lead to Food Authentication? A Systematic Review from A European Perspective. Food Rev. Int. 2021, 1-23. [CrossRef]

66. Skalkos, D.; Kosma, I.S.; Vasiliou, A.; Guine, R.P.F. Consumers' Trust in Greek Traditional Foods in the Post COVID-19 Era. Sustainability 2021, 13, 9975. [CrossRef]

67. Savelli, E.; Bravi, L.; Francioni, B.; Murmura, F.; Pencarelli, T. PDO Labels and Food Preferences: Results from a Sensory Analysis. Br. Food J. 2021, 123, 1170-1189. [CrossRef]

68. Kos Skubic, M.; Erjavec, K.; Klopčič, M. Consumer Preferences Regarding National and EU Quality Labels for Cheese, Ham and Honey: The Case of Slovenia. Br. Food J. 2018, 120, 650-664. [CrossRef]

69. Skalkos, D.; Kosma, I.S.; Chasioti, E.; Bintsis, T.; Karantonis, H.C. Consumers' Perception on Traceability of Greek Traditional Foods in the Post-COVID-19 Era. Sustainability 2021, 13, 12687. [CrossRef]

70. Petrescu-Mag, R.M.; Vermeir, I.; Petrescu, D.C.; Crista, F.L.; Banatean-Dunea, I. Traditional Foods at the Click of a Button: The Preference for the Online Purchase of Romanian Traditional Foods during the COVID-19 Pandemic. Sustainability 2020, 12, 9956. [CrossRef]

71. Brugarolas, M.; Martínez-Carrasco, L.; Rabadán, A.; Bernabéu, R. Innovation Strategies of the Spanish Agri-Food Sector in Response to the Black Swan COVID-19 Pandemic. Foods 2020, 9, 1821. [CrossRef] [PubMed]

72. Alaimo, L.S.; Fiore, M.; Galati, A. Measuring Consumers' Level of Satisfaction for Online Food Shopping during COVID-19 in Italy Using POSETs. Socioe-Econ. Plan. Sci. 2021, 101064. [CrossRef]

73. Alaimo, L.S.; Fiore, M.; Galati, A. How the Covid-19 Pandemic Is Changing Online Food Shopping Human Behaviour in Italy. Sustainability 2020, 12, 9594. [CrossRef]

74. Vidaurreta, I.; Orengo, J.; Fe, C.; González, J.M.; Gómez-Martín, Á.; Benito, B. Price Fluctuation, Protected Geographical Indications and Employment in the Spanish Small Ruminant Sector during the COVID-19 Crisis. Animals 2020, 10, 2221. [CrossRef] 